Web Jurnal:

http://ejournal.kemenperin.go.id/jli

Jurnal Litbang Industri

| p-ISSN: 2252-3367 | e-ISSN: 2502-5007 |

\title{
Pemanfaatan limbah lumpur aktif (LLA) sebagai adsorben untuk meminimalisir zat pencemar dalam air dan air limbah : Sebuah Ulasan
}

\section{Utilization of activated sludge (LLA) as an adsorbent to minimize contaminants in water and wastewater: A Review}

\author{
Salmariza. Sy* \\ Balai Riset dan Standardisasi Industri Padang. \\ J1. Raya LIK No. 23 Ulu Gadut, Padang Indonesia \\ * e-mail: rizasalma@gmail.com
}

\begin{tabular}{l}
\hline INFO ARTIKEL \\
\hline Sejarah artikel: \\
Diterima: \\
13 November 2020 \\
Direvisi: \\
16 Desember 2020 \\
Diterbitkan: \\
28 Desember 2020
\end{tabular}

\section{Kata kunci:}

adsorben;

limbah lumpur aktif;

LLA;

adsorben berbasis

lumpur;

$\mathrm{ABL}$

\section{Keywords:}

adsorbent;

waste activated sludge;

LLA;

sludge based

adsorbents;

$A B L$

\begin{abstract}
ABSTRAK
Artikel review ini merangkum tentang pemanfaatan limbah lumpur aktif (LLA) sebagai bahan prekursor untuk menghasilkan adsorben dan aplikasinya terhadap material pencemar lingkungan seperti pewarna dan logam berat. Kinerja adsorben berbasis lumpur $(\mathrm{ABL})$ telah direview, dimana hasilnya bervariasi tergantung pada jenis prekursor lumpur, jenis pencemar, waktu dan suhu karbonisasi dan jenis kondisi aktivasi yang digunakan. Hasil review menunjukkan bahwa aktivasi kimia secara langsung mempengaruhi sifat adsorben, kapasitas adsorpsi dan mekanisme penyisihan zat pencemar oleh ABL. Dilaporkan bahwa aktivasi kimiawi menggunakan berbagai jenis aktivator menghasilkan adsorben yang jauh lebih unggul dengan luas spesifik area yang tinggi dibandingkan dengan metode aktivasi secara fisika. Disamping itu pada proses aktifvasi fisika sendiri, dilaporkan bahwa sejalan dengan semakin tinggi suhu pirolisis dan suhu aktivasi, maka semakin dapat meningkatkan luas spesifik area sehingga dapat meningkatkan kapasitas penjerapan zat warna dan logam dalam larutan.
\end{abstract}

\begin{abstract}
This review article summarizes the use of waste activated sludge (LLA) as a precursor to produce adsorbents and its application to environmental pollutants such as dyes and heavy metals. The performance of the sludge-based adsorbent (ABL) has been reviewed, where the results vary depending on the type of sludge precursor, type of pollutant, carbonization time and temperature and the type of activation condition used. The results of the review show that chemical activation directly affects the adsorbent properties, adsorption capacity and the pollutant removal mechanism by ABL. It was reported that chemical activation method, using various types of activators produced more superior adsorbents with a high specific area compared to physical one. Besides that, in the physical activation process itself, it was reported that in line with the higher the pyrolysis temperature and the activation temperature, the more it can increase the specific area so that result increasing the adsorption capacity of dyes and metals in solution.
\end{abstract}

\section{Pendahuluan}

Limbah lumpur adalah produk samping utama dari pengolahan air limbah pabrik (Boualem et al., 2014). Diperkirakan kebutuhan pengolahan air limbah akan meningkat sesuai perkembangan kebutuhan hidup akibat gelombang industrialisasi dan urbanisasi. Oleh karena itu peningkatan jumlah limbah lumpur yang diproduksi dari instalasi pengolahan air limbah juga akan meningkat.
Limbah lumpur ini dikenal dengan istilah Limbah Lumpur Aktif (LLA) yang saat ini telah disadari telah menjadi beban ekologis bagi masyarakat (Hadi et al., 2015; S. Sy et al., 2018; Salmariza Sy et al., 2018b), dimana pengelolaan dan pembuangannya menjadi masalah besar bagi kota dan industri (Devi and Saroha, 2017; S. Sy et al., 2018; Salmariza Sy et al., 2018b). Contoh kasus di Eropa, produksi limbah lumpur dari pengolahan air limbah kota diperkirakan 11,5 juta ton 
pada tahun 2010, yang diperkirakan akan meningkat menjadi 13,0 juta ton pada tahun 2020. Akibatnya, penanganan dan pembuangannya merupakan masalah yang menjadi perhatian khusus (Samolada and Zabaniotou, 2014)

Perlakuan dan pembuangan LLA yang tidak tepat akan menyebabkan masalah lingkungan sekunder seperti emisi gas rumah kaca dan kontaminasi pada permukaan tanah (Devi and Saroha, 2017; S. Sy et al., 2018; Salmariza Sy et al., 2018b). Oleh karena itu diperlukan pengelolaan LLA yang tepat (Samolada and Zabaniotou, 2014). Selama ini pembuangan yang dilakukan meliputi tempat pembuangan akhir sampah (TPA), penimbun jalan, keperkebunan, reklamasi hutan dan lahan dan sebagai material bahan bangunan (Ding et al., 2012; Salmariza Sy et al., 2018a). Metode pembuangan lumpur tradisional seperti pembuangan ke TPA dan lahan pertanian mendapat hambatan besar karena kurangnya lokasi TPA yang tersedia dan tingginya kemungkinan pencemaran lahan pertanian. Selain itu pembuangan ke TPA lebih lanjut menjadi dilema karena terjadinya peningkatan biaya yang sejalan dengan waktu (Smith et al., 2009).

Metode lain untuk menambahkan nilai pada LLA adalah dengan pembakaran diinsinerator, yang dapat menghasilkan energi tinggi dan mengurangi volume pembuangan akhir. Namun, teknik ini juga memiliki keterbatasan, yaitu prosesnya akan menghasilkan dioksin dan produk samping pembakaran yang beracun (GómezPacheco et al., 2012). Selain itu biaya energi operasional insinerasi cukup mahal (sekitar 210-310 V/ton padatan kering), dan pembakaran di insenerator dapat menimbulkan abu yang banyak dan berpotensi menimbulkan bahaya bagi manusia dan lingkungan (Rio et al., 2006).

Pemanfaatan LLA sebagai adsorben merupakan salah satu solusi yang ditawarkan dan mendapat perhatian akhir-akhir ini (Monsalvo et al., 2011). Selanjutnya mendapatkan lumpur sebagai bahan yang kaya karbon, telah membuka peluang baru untuk memproduksi karbon aktif yang dapat diaplikasikan dalam pengolahan air dan air limbah (Hadi et al., 2015). Artikel ini meriview penelitian yang dipublikasikan di bidang pemanfaatan LLA sebagai adsorben. Namun, sebelum membahas hal ini, perlu untuk menggambarkan apa yang dimaksud dengan LLA, jenis LLA, karbon aktif dan metoda pembuatannya menjadi adsorben.

\section{Defenisi dan jenis limbah lumpur}

Limbah lumpur dapat didefinisikan sebagai residu yang dihasilkan dari pengolahan limbah cair. Berdasarkan asal-usul limbah lumpur, limbah lumpur dapat dibagi menjadi dua kategori: (i) limbah lumpur primer dan (ii) limbah lumpur sekunder. Limbah lumpur primer terutama bersifat anorganik dan diproduksi selama operasi pengolahan air limbah primer seperti proses sedimentasi, filtrasi, koagulasi dan floatation (Devi and Saroha, 2017; Smith et al., 2009). Limbah lumpur sekunder juga dikenal sebagai lumpur biologis (BS), bersifat biologis, merupakan lumpur yang dihasilkan dari pengolahan air limbah secara biologis yang dialirkan dari tangki pengendapan. Perlakuan sekunder yang melibatkan proses biologis menghasilkan residu yang mengandung campuran kompleks senyawa organik yang tidak dicerna dan mikroorganisme mati. Namun, karakteristik akhir dari residu semacam itu dapat sangat bervariasi tergantung pada asal lumpur, jenis perlakuan yang diterapkan dan bahkan agen koagulasi yang digunakan (Smith et al., 2009). Selama pengolahan air limbah sekunder, mikroba menurunkan BOD dari air limbah dengan menurunkan tingkat organik yang ada saat ini dalam air limbah yang pada gilirannya mengarah pada produksi biomassa mikroba yang diakumulasi sebagai lumpur sekunder (Devi and Saroha, 2017).

Selain itu ada limbah lumpur kimia, yang merupakan bentuk lain dari lumpur yang biasa terjadi, dan merupakan lumpur yang telah diproduksi dengan bantuan bahan kimia. Biasanya bahan kimia digunakan baik untuk memfasilitasi pengendapan bahan yang sulit dihilangkan, atau untuk meningkatkan penghilangan padatan tersuspensi (Turovskiy and Mathai, 2005).

\section{Komponen limbah lumpur aktif (LLA)}

LLA memiliki komponen utama yang sama dengan lumpur aktif yaitu berupa mikroorganisme, namun dalam kondisi yang berbeda, dimana kondisi mikroorganisme dalam lumpur aktif masih dalam keadaan hidup, sementara itu mikroorganisme didalam LLA sudah dalam keadaan mati atau kemungkinan ada yang dalam keadaan dormansi, karena telah dikeringkan (Salmariza, 2012; Spellman, 2014; Salmariza Sy et al., 2018a). Pembentukan sel mikroorganisme tersebut tergantung pada komposisi kimia air limbah dan karakteristik khusus dari organisme dalam komunitas biologis (Spellman, 2014). Menurut laporan (Gadd and White, 1993), mikroorganisme seperti, khamir, jamur, bakteri dan alga secara efisien dapat menyerap logam-logam berat dan radionuklida dari lingkungan eksternalnya. Proses ini berlangsung cepat dan terjadi baik pada mikroorganisme hidup maupun mati. Selain mengandung banyak mikroba, LLA juga mengandung berbagai kontaminan lainnya yang tergantung pada sumbernya.

Karakterisasi LLA dengan XRF (X-ray fluorescence spectrometer) menunjukkan adanya kandungan elemen $\mathrm{C}, \mathrm{O}, \mathrm{Si}$, dan $\mathrm{Ca}$ dan dalam bentuk oksida $\mathrm{Al}_{2} \mathrm{O}_{3}, \mathrm{SiO}_{2}$, $\mathrm{CaO}$ yang tinggi. Namun umumnya kandungan elemen menurun setelah pencucian dan pirolisis. $\mathrm{Al}_{2} \mathrm{O}_{3}, \mathrm{SiO}_{2}$, dan $\mathrm{CaO}$ adalah komposisi kimia oksida dominan dalam lumpur (Abo-El-Enein et al., 2017). Sebagian besar elemen terlepas saat proses perendaman dan pencucian lumpur dalam kondisi asam (Zaini et al., 2013). Begitu juga, sebagian besar organik yang mudah menguap terbakar habis saat proses pirolisis (Chiang et al., 2012; S. Sy et al., 2018). Komposisi komponen utama dalam ABL dari beberapa jenis lumpur disajikan pada Tabel 1. 
Tabel 1.

Komposisi komponen utama dalam ABL dari beragam asal lumpur aktif (LLA)

\begin{tabular}{|c|c|c|c|c|c|c|c|}
\hline \multirow[t]{2}{*}{ Asal Lumpur } & \multicolumn{6}{|c|}{ Komponen utama $(\%, \mathrm{~g} / \mathrm{kg})$} & \multirow[t]{2}{*}{ Pustaka } \\
\hline & $\mathrm{Si} / \mathrm{SiO}_{2}$ & $\mathrm{Al} / \mathrm{AlO}_{2}$ & $\mathrm{Fe} / \mathrm{Fe}_{2} \mathrm{O}_{3}$ & $\mathrm{Ca} / \mathrm{CaO}$ & $\mathrm{C}$ & $\begin{array}{l}\mathrm{Mg} / \mathrm{Mg} \\
\mathrm{O}\end{array}$ & \\
\hline Pabrik karet remah & 63,2 & 16,1 & 3,2 & 18,4 & 43,4 & 0,22 & (S. Sy et al., 2018) \\
\hline Instalasi air minum & 36,51 & 22,21 & 5,65 & 2,66 & & 1,34 & (Abo-El-Enein et al., 2017) \\
\hline Industri pengolahan ikan & 46,0 & 12,6 & 14,8 & 13,8 & - & - & (Nielsen et al., 2015) \\
\hline Pabrik CPO (Sawit) & 24,1 & 25,2 & 5,9 & 0,6 & 19,1 & 12,5 & (Zaini et al., 2014) \\
\hline Pabrik palstik dan pupuk & 63,2 & 4,0 & 6,8 & 87,7 & 34,6 & 6,5 & Velghe 2012 \\
\hline Industri makanan & - & - & - & - & 41,4 & - & (Mahapatra et al., 2012) \\
\hline Industri baja & 12,6 & & 48 & 23,4 & & 2,5 & (Naiya et al., 2008) \\
\hline Pabrik kertas & 16,1 & 13,6 & 0,4 & 14,2 & 52,2 & 2,8 & (Hojamberdiev et al., 2008) \\
\hline IPAL komunal & 15,7 & 3,0 & 1,6 & 0,4 & 60,2 & 0,5 & (Lin et al., 2012) \\
\hline Instalasi air minum & 23.75 & 11.65 & 9.64 & 21.81 & & 4.13 & (Gómez-Pacheco et al., 2012) \\
\hline Pabrik kertas & 28,28 & 14,92 & 15,35 & 22,08 & & 6,22 & (W.-H. Li et al., 2011) \\
\hline
\end{tabular}

\section{Karbon aktif}

Karbon aktif adalah bahan berkarbon dengan derajat porositas tinggi dan luas permukaan partikulat yang luas biasanya melalui proses seperti pembakaran parsial atau dekomposisi termal (Smith et al., 2009). Secara umum karbon aktif, atau sering juga disebut sebagai arang aktif, didefinisikan sebagai suatu jenis karbon yang memiliki luas permukaan yang sangat besar. Hal ini bisa dicapai dengan mengaktifkan karbon atau arang tersebut. Hanya dengan satu gram dari karbon aktif, akan didapatkan suatu material yang memiliki luas permukaan kira-kira sebesar $500 \mathrm{~m}^{2}$ (didapat dari pengukuran adsorpsi gas nitrogen). Biasanya pengaktifan hanya bertujuan untuk memperbesar luas permukaannya saja, tetapi beberapa usaha juga berkaitan dengan meningkatkan kemampuan adsorpsi karbon aktif itu sendiri.

\section{Adsorben berbasis lumpur (ABL)}

Laporan perjalanan sejarah tentang potensi lumpur sebagai bahan baku untuk memproduksi karbon aktif, yang berasal dari sifatnya yang berkarbon, pertama kali dilaporkan oleh Kemmer dan kawan-kawan pada tahun 1971. Mereka telah mematenkan suatu proses untuk memproduksi adsorben dengan aktivasi kimia dari lumpur limbah kering. Pada tahun yang sama, Beeckmans dan $\mathrm{Ng}$ juga menghasilkan penelitian pertama tentang produksi adsorben dari lumpur limbah secara proses karbonisasi. Studi awal lainnya termasuk yang dilakukan oleh Bojner pada tahun 1973 yang melaporkan bahwa ABL dapat diproduksi dengan biaya rendah yaitu sekitar $10 \%$ dari biaya karbon aktif normal. Kemudian dilanjutkan dengan laporan Humphrey dan kawan-kawan pada tahun 1974 dan 1976, tentang pengembangan sistem pengolahan air limbah siklik yang menggabungkan fasilitas di tempat untuk produksi adsorben berbasis limbah lumpur (ABLL) dengan aktivasi uap, regenerasi ABLL dan pembakaran ABLL yang dihabiskan untuk pemulihan energi. Setelah studistudi yang telah dilaporkan tadi, sampai saat ini, telah banyak penelitian tentang produksi ABLL dilakukan dan dilaporkan (Smith et al., 2009).
Limbah lumpur mempunyai kandungan substansi organik yang tinggi, berdasarkan hal itu, lumpur telah diusulkan sebagai alternatif yang menjanjikan untuk memproduksi padatan karbon berpori melalui pirolisis (Calisto et al., 2014). Adsorben berbasis lumpur (ABL) dapat digunakan untuk menghilangkan fenol, logam berat, pewarna, dan polutan organik lainnya dari larutan (Smith et al., 2009). Menggunakan lumpur sebagai bahan baku berbiaya rendah dengam menggunakan teknologi termal, sangat menguntungkan dalam mengubah lumpur menjadi produk bernilai tambah, dapat mengurangi volume limbah dan mengekstraksi energi yang bermanfaat untuk mempertahankan dan mengeksplor limbah itu sendiri. ABL memiliki stabilitas termal yang sangat baik, dan toksisitas pencuciannya tetap berada dalam tingkat yang aman (Calisto et al., 2014; Xu et al., 2015).

Pada penelitian sebelumnya, banyak peneliti telah menggunakan limbah lumpur dan lumpur industri untuk membuat adsorben berbasis limbah lumpur (SBA) yang merupakan alternatif karbon aktif berbiaya rendah dan memiliki aplikasi yang luas dan efisien dalam menyerap zat warna yang berbeda (Jindarom et al., 2007; Zaini et al., 2013; Zou et al., 2013), logam berat (Agrafioti et al., 2013; Almquist and Qin, 2013; Salmariza Sy et al., 2018a; Velghe et al., 2012; Zaini et al., 2013; Zhang et al., 2013) dan bahkan dalam menghilangkan kontaminan gas (Boualem et al., 2014).

\section{Persiapan karbon aktif dari ABL}

Kondisi persiapan dan aktivasi ABL sangat mempengaruhi sifat dan kapasitas adsorpsi adsorben berbasis lumpur untuk menghilangkan pewarna dan logam berat. Beragam metode persiapan ABL telah dilaporkan. Beberapa penelitian menggunakan proses pengeringan limbah lumpur saja, dengan perlakuan awal atau pre-treatment dan sebagian dengan proses termal dengan penekanan pada karbonisasi dan aktivasi limbah lumpur (Xu et al., 2015). Beberapa faktor yang mempengaruhi efisiensi penyisihan zat pencemar oleh karbon aktif adalah struktur berpori dan gugus fungsi permukaannya (Hadi et al., 2015). Struktur berpori 
karbon aktif dapat dimanipulasi dengan mengubah parameter aktivasi, seperti jenis aktivasi (fisika dan/atau kimia), zat pengaktif, suhu pirolisis/aktivasi, rasio impregnasi (didefinisikan, sebagai berat rasio kimia pengaktifan ke prekursor) dan pirolisis/urutan aktivasi. Jenis aktivator juga sangat penting untuk mengontrol jenis gugus fungsi yang sesuai pada permukaan material. Oleh karena itu, persiapan ABL yang cermat akan berefek dramatis terhadap karakteristik sifat fisikokimia ABL yang dihasilkan (Hadi et al., 2015). Beberapa penelitian telah melaporkan pengaruh kondisi pirolisis dan aktivasi pada penyisihan pewarna dan logam berat menggunakan adsorben berbasis lumpur (Athalathil et al., 2014; Jindarom et al., 2007; Velghe et al., 2012; Xi and Guo, 2013; Zaini et al., 2014, 2013) (Tabel 2).

Aktivasi secara fisika dan kimia adalah dua metode utama untuk persiapan karbon aktif (Hadi et al., 2015; $\mathrm{Xu}$ et al., 2015). Aktivasi karbon secara fisika biasanya dilakukan melalui proses dua langkah. Pada langkah pertama, bahan dipirolisis pada suhu yang relatif rendah tanpa adanya udara. Arang yang dihasilkan adalah material dengan luas permukaan sedang dengan hampir tidak ada aktivitas untuk sekresi zat pencemar. Langkah kedua adalah aktivasi arang yang telah terbentuk dengan melibatkan pengoksidasi (biasanya Gas inert) guna meningkatkan luas permukaannya, sehingga terjadi pengembangan porositas yang meningkatkan efisiensi penyisihan. Beberapa literatur telah mengintegrasikan kedua proses ini dan telah mengembangkan metode aktivasi satu tahap. Hal ini dapat menghemat energi, menghasilkan karbon yang lebih tinggi, biaya modal dan operasional yang lebih rendah dan waktu pemprosesan yang lebih sedikit, sehingga dapat mengurangi biaya produksi karbon aktif (Hadi et al., 2015).

Di sisi lain, aktivasi kimiawi adalah proses satu langkah di mana prekursor berkarbon direndam dalam zat dehidrasi, seperti kalium hidroksida, asam fosfat dan seng klorida, dan kemudian diaktifkan pada suhu yang relatif tinggi di bawah gas inert (inert atmosfir). Teknik aktivasi kimia lebih memberikan beberapa keuntungan dibandingkan metode aktivasi secara fisika, yaitu suhu aktivasi rendah, perlakuan panas yang lebih pendek dan hasil karbon yang lebih tinggi, meskipun biaya bahan pengaktif yang tinggi dan membutuhkan pencucian ekstra (Hadi et al., 2015).

Tabel 2.

Metoda aktivasi yang digunakan dalam persiapan ABL dari berbagai jenis (LLA)

\begin{tabular}{|c|c|c|c|c|c|c|}
\hline \multirow[t]{2}{*}{ Jenis Lumpur ABL } & \multicolumn{2}{|c|}{ Aktivasi } & \multicolumn{2}{|c|}{ Kondisi Karbonasi } & \multirow[t]{2}{*}{$\mathrm{S} \operatorname{BET}\left(\mathrm{m}^{2} / \mathrm{g}\right)$} & \multirow[t]{2}{*}{ Pustaka } \\
\hline & Fisika & Kimia & Suhu $\left({ }^{\circ} \mathrm{C}\right)$ & Atmosfir & & \\
\hline \multirow[t]{4}{*}{ IPAL Komunal } & - & - & - & - & 2.48 & (Gao et al., 2019) \\
\hline & $\sqrt{ }$ & & 300 & $\mathrm{~N}_{2}$ & 6,08 & \\
\hline & $\sqrt{ }$ & & 500 & $\mathrm{~N}_{2}$ & 8,50 & \\
\hline & $\sqrt{ }$ & & 700 & $\mathrm{~N}_{2}$ & 34,80 & \\
\hline IPAL Industri Kertas & $\sqrt{ }$ & - & 800 & Steam & 79,65 & (W. H. Li et al., 2011) \\
\hline \multirow{2}{*}{ IPAL Industri CPO } & $\sqrt{ }$ & $\sqrt{ }$ & 500 & - & 29,2 & (Zaini et al., 2013) \\
\hline & $\sqrt{ }$ & $\sqrt{ }$ & 500 & - & 79,4 & \\
\hline IPAL Industri Karet & $\sqrt{ }$ & - & 600 & - & 2,516 & (S. Sy et al., 2018; Sy et al., 2016) \\
\hline Remah & $\sqrt{ }$ & $\sqrt{ }$ & 600 & - & 52,180 & \\
\hline IPAL komunal & $\sqrt{ }$ & - & 400 & $\mathrm{~N}_{2}$ & 23,7 & (Zhang et al., 2013) \\
\hline \multirow[t]{2}{*}{ IPAL Industri Kertas } & $\sqrt{ }$ & - & 600 & Udara & 22 & (Hojamberdiev et al., 2008) \\
\hline & $\sqrt{ }$ & - & 600 & Steam & 70 & \\
\hline \multirow[t]{2}{*}{ IPAL komunal } & $\sqrt{ }$ & $\sqrt{ }$ & 300 & $\mathrm{~N}_{2}$ & 18 & (Agrafioti et al., 2013) \\
\hline & $\sqrt{ }$ & $\sqrt{ }$ & 500 & $\mathrm{~N}_{2}$ & 90 & \\
\hline \multirow[t]{2}{*}{ IPAL komunal } & $\sqrt{ }$ & - & 750 & $\mathrm{~N}_{2}$ & 34,3 & (Jindarom et al., 2007) \\
\hline & $\sqrt{ }$ & & 750 & $\mathrm{CO}_{2}$ & 60,7 & \\
\hline \multirow[t]{2}{*}{ IPAL komunal } & $\sqrt{ }$ & $\sqrt{ }$ & 500 & $\mathrm{~N}_{2}$ & 97.431 & (Zou et al., 2013) \\
\hline & $\sqrt{ }$ & $\sqrt{ }$ & 600 & $\mathrm{~N}_{2}$ & 121.263 & \\
\hline \multirow[t]{3}{*}{ IPAL Industri Kertas } & $\sqrt{ }$ & - & 600 & $\mathrm{~N}_{2}$ & 50 & (Almquist and Qin, 2013) \\
\hline & $\sqrt{ }$ & - & 750 & $\mathrm{~N}_{2}$ & 49 & \\
\hline & $\sqrt{ }$ & - & 900 & $\mathrm{~N}_{2}$ & 67 & \\
\hline IPAL Industri & $\sqrt{ }$ & - & 400 & udara & 91 & (Monsalvo et al., 2011) \\
\hline Kosmetik & $\sqrt{ }$ & - & 800 & $\mathrm{CO}_{2}$ & 97 & \\
\hline \multirow[t]{3}{*}{ IPAL komunal } & $\sqrt{ }$ & - & $<450$ & $\mathrm{~N}_{2}$ & 15 & (Velghe et al., 2012) \\
\hline & $\sqrt{ }$ & - & 450 & $\mathrm{~N}_{2}$ & 60 & \\
\hline & $\sqrt{ }$ & $\sqrt{ }$ & 450 & $\mathrm{~N}_{2}$ & 257 & \\
\hline \multirow[t]{3}{*}{ IPAL komunal } & $\sqrt{ }$ & $\sqrt{ }$ & 600 & $\mathrm{~N}_{2}$ & 104.5 & (Lin et al., 2012) \\
\hline & $\sqrt{ }$ & $\sqrt{ }$ & 600 & $\mathrm{~N}_{2}$ & 118.3 & \\
\hline & $\sqrt{ }$ & $\sqrt{ }$ & 600 & $\mathrm{~N}_{2}$ & 130.7 & \\
\hline \multirow[t]{4}{*}{ IPAL komunal } & $\sqrt{ }$ & $\sqrt{ }$ & 400 & $\mathrm{~N}_{2}$ & 89 & (Chiang et al., 2012) \\
\hline & $\sqrt{ }$ & $\sqrt{ }$ & 500 & $\mathrm{~N}_{2}$ & 371 & \\
\hline & $\sqrt{ }$ & $\sqrt{ }$ & 600 & $\mathrm{~N}_{2}$ & 538 & \\
\hline & $\sqrt{ }$ & $\sqrt{ }$ & 700 & $\mathrm{~N}_{2}$ & 490 & \\
\hline IPAL Komunal & $\sqrt{ }$ & $\sqrt{ }$ & 700 & $\mathrm{~N}_{2}$ & 139 & (Gómez-Pacheco et al., 2012) \\
\hline
\end{tabular}




\section{Pengaruh kondisi persiapan dan aktivasi terhadap penyerapan pewarna}

Variasi pirolisis dan kondisi aktivasi ABL berperan penting dalam menentukan kapasitas adsorpsi ABL untuk menjerap zat warna. Hal ini diamati dari literatur bahwa efisiensi penjerapan zat warna berhubungan langsung dengan luas permukaan dan volume pori dari adsorben. Efisiensi dekolorisasi ABL ditemukan meningkat dengan peningkatan suhu karbonisasi karena terjadinya pengembangan luas permukaan dan volume pori yang tinggi pada suhu pirolisis yang meningkat (Athalathil et al., 2014) (Tabel 3). Sebuah studi menunjukkan bahwa luas permukaan prekursor lumpur porositas rendah $\left(3,4 \mathrm{~m}^{2} / \mathrm{g}\right)$ meningkat menjadi $14,0 \mathrm{~m}^{2} / \mathrm{g}$ ketika dipirolisis pada suhu $350^{\circ} \mathrm{C}$ dengan menggunakan gas nitrogen. Terlihat terjadi peningkatan luas permukaan arang menjadi $34,3 \mathrm{~m}^{2} / \mathrm{g}$ dengan meningkatkan suhu pirolisis hingga $750^{\circ} \mathrm{C}$ (Jindarom et al., 2007). Pada penelitian lain juga dilaporkan, terjadi pengembangan luas permukaan dan mikropori yang lebih tinggi, pada suhu yang jauh lebih rendah $\left(300^{\circ} \mathrm{C}\right)$ dalam adsorben lumpur yang dibuat dengan aktivasi fisika/kimia dibandingkan dengan adsorben yang dibuat tanpa aktivasi fisika/kimia, meskipun dengan suhu yang lebih tinggi $\left(700^{\circ} \mathrm{C}\right)(\mathrm{W} . \mathrm{H}$. Li et al., 2011).

Perubahan atmosfer pirolisis dari menggunakan gas $\mathrm{N}_{2}$ menjadi $\mathrm{CO}_{2}$ juga telah dipelajari dan dampak dramatis pada peningkatan perkembangan porositas telah diamati pada suhu tinggi, di mana luas permukaan adsorben lumpur pada suhu $750^{\circ} \mathrm{C}$ dengan adanya aliran $\mathrm{CO}_{2}$ telah meningkat menjadi $60,7 \mathrm{~m}_{2} / \mathrm{g}$ karena efek gasifikasi gas (Jindarom et al., 2007) (Tabel 2). Karbon dioksida dapat menghilangkan atom karbon dari bagian dalam partikel, yang mengarah pada pembentukan poripori baru dan pembesaran mikropori (Hadi et al., 2015).

Tabel 3

Perbandingan S BET dan Kapasitas penjerapan zat warna oleh beberapa ABL

\begin{tabular}{|c|c|c|c|c|c|}
\hline \multirow[t]{2}{*}{ Zat warna } & \multicolumn{2}{|c|}{ Kondisi karbonasi dan aktivasi } & \multirow{2}{*}{$\begin{array}{l}\text { S BET } \\
\left(\mathrm{m}^{2} / \mathrm{g}\right)\end{array}$} & \multirow{2}{*}{$\begin{array}{l}\text { Kapasitas } \\
\text { adsorpsi (mg/g) }\end{array}$} & \multirow[t]{2}{*}{ Pustaka } \\
\hline & Suhu $\left({ }^{\circ} \mathrm{C}\right)$ & Kimia & & & \\
\hline \multirow[t]{2}{*}{ Methylene blue } & 700 & $\mathrm{NaOH}$ & 139 & 100 & (Gómez-Pacheco et al., 2012) \\
\hline & - & - & 3,4 & - & (Jindarom et al., 2007) \\
\hline Acid yellow 49 & $750 \mathrm{~N}_{2}$ & & 34,3 & 71,43 & \\
\hline Basic blue, & $750 \mathrm{~N}_{2}$ & & 34,3 & 416,67 & \\
\hline Reactive red 198 & $750 \mathrm{~N}_{2}$ & & 34,3 & 18,93 & \\
\hline Acid yellow, & $750 \mathrm{CO}_{2}$ & & 60,7 & 116,28 & \\
\hline Basic blue, & $750 \mathrm{CO}_{2}$ & & 60,7 & 588,24 & \\
\hline \multirow[t]{2}{*}{ Reactive red } & $750 \mathrm{CO}_{2}$ & & 60,7 & 25,26 & \\
\hline & - & $\mathrm{H}_{3} \mathrm{PO}_{4}$ & 7,78 & 88 & (Abbas et al., 2017) \\
\hline \multirow[t]{2}{*}{ Methylene blue } & - & $\mathrm{HCl}$ & 7,84 & 140 & \\
\hline & - & $\mathrm{KOH}$ & 5,39 & 200 & \\
\hline \multirow[t]{2}{*}{ Methylene blue } & 500 & $\mathrm{ZnCl}_{2}$ & 29,2 & 22,4 & (Zaini et al., 2013) \\
\hline & 500 & $\mathrm{KOH}$ & 79,4 & 23,5 & \\
\hline \multirow[t]{2}{*}{ Rhodamine $B$} & 500 & $\mathrm{NaOH}$ & 97,431 & & (Zou et al., 2013) \\
\hline & 600 & $\mathrm{NaOH}$ & 121,263 & 27.701 & \\
\hline \multirow[t]{3}{*}{ Acid Orange II } & 400 & $\mathrm{ZnCl}_{2}$ & 13 & 4,5 & (Athalathil et al., 2014) \\
\hline & 600 & - & 111,3 & 96,15 & \\
\hline & 800 & - & 202,2 & 98,03 & \\
\hline \multirow[t]{2}{*}{ Methylene blue } & 300 & Steam $800^{\circ} \mathrm{C}$ & 135,49 & 130,69 & (W. H. Li et al., 2011) \\
\hline & 700 & - & 79,65 & 25,44 & \\
\hline
\end{tabular}

Penggunaan karbon dioksida sebagai pengganti gas Nitrogen dalam proses pirolisis telah menghasilkan pembentukan struktur yang lebih mikro pada suhu tinggi. Hal ini dapat dilihat bahwa penerapan gas pengoksidasi (terutama uap) sebagai pengganti gas inert memiliki efek yang cukup besar pada luas permukaan, volume mikropori dan ukuran pori dari karbon yang dibuat. Namun, seperti terlihat pada Tabel 2, sebagian besar penelitian hanya menggunakan Nitrogen sebagai atmosfer inert tanpa mencoba meningkatkan luas permukaan dengan penerapan gas pengoksidasi. Ada dua kelemahan utama dalam pengolahan adsorben berbasis lumpur. Pertama, sebagian besar literatur terbatas pada produksi arang dan belum mencoba untuk mengaktifkan arang yang disiapkan, sedangkan karakter pirolisis dengan tanpa agen pengoksidasi umumnya menghasilkan lumpur aktif dengan luas spesifik area yang rendah dengan kapasitas adsorpsi yang rendah juga, sehingga harus diaktifkan untuk menghasilkan karbon aktif dengan spesifik area yang tinggi dan sebanding dengan efisiensi penyisihannya. Kelemahan kedua adalah suhu rendah yang digunakan dalam beberapa penelitian untuk pirolisis/aktivasi karbon. Sebagian besar literatur yang terkait dengan aktivasi bahan berkarbon mencapai luas permukaan yang tinggi pada suhu di atas $700^{\circ} \mathrm{C}$. Oleh karena itu, karakter aktivasi yang dihasilkan pada suhu yang lebih tinggi dan dengan adanya gas pengoksidasi diyakini akan lebih meningkatkan spesifik area adsorben yang dihasilkan dan selanjutnya akan meningkatkan kapasitas penjerapannya (Hadi et al., 2015).

Pengaruh aktivasi kimia dan penambahan aktivator pada kapasitas adsorpsi ABL juga dilaporkan dalam literatur. (Gómez-Pacheco et al., 2012; W.-H. Li et al., 2011). Ditemukan bahwa kapasitas adsorpsi Metilen Blue meningkat secara signifikan setelah diaktivasi dengan $\mathrm{NaOH}$ karena pengayaan gugus fungsi $\mathrm{OH}$ pada permukaan adsorben. Sebaliknya, kapasitas penjerapan berkurang dengan penambahan zat pengikat sebelum aktivasi (asam humat, resin fenolik, dan tanah liat). 
Penambahan pengikat fenolik menurunkan luas permukaan adsorben tetapi sifat permukaan adsorben tetap sama. Namun, penambahan bahan pengikat meningkatkan sifat butiran lumpur, sehingga meningkatkan aplikasi komersialnya (Abbas et al., 2017; Gómez-Pacheco et al., 2012). Lebih lanjut, sifat dan asal lumpur juga memainkan peran penting dalam menentukan kapasitas adsorpsi ABL. Dilaporkan (Pan et al., 2011) telah menyiapkan adsorben dengan aktivasi $\mathrm{H}_{2} \mathrm{SO}_{4}$ dari tiga jenis lumpur yaitu; lumpur biologis, lumpur kimiawi dan lumpur hibrida (biologis+kimiawi) dan menemukan bahwa lumpur kimiawi dan hibrida berkinerja lebih baik daripada lumpur biologis karena struktur berpori mereka (meso- dan makroporous) dan reaktivitas permukaan yang tinggi (gugus fungsi asam). Efisiensi adsorpsi yang buruk dari adsorben berbasis lumpur biologis mungkin disebabkan oleh kandungan logam yang rendah dan kelimpahan yang berlebihan dari gugus fungsi asam pada permukaan adsorben (Devi and Saroha, 2017).

Tabel 4

Perbandingan S BET dan Kapasitas penjerapan logam oleh beberapa ABL

\begin{tabular}{|c|c|c|c|c|c|}
\hline \multirow[t]{2}{*}{ Logam } & \multicolumn{2}{|c|}{$\begin{array}{c}\text { Kondisi karbonasi dan } \\
\text { aktivasi }\end{array}$} & \multirow[t]{2}{*}{$\mathrm{S} \mathrm{BET}\left(\mathrm{m}^{2} / \mathrm{g}\right)$} & \multirow[t]{2}{*}{$\begin{array}{l}\text { Kapasitas Adsorpsi } \\
(\mathrm{mg} / \mathrm{g})\end{array}$} & \multirow[t]{2}{*}{ Pustaka } \\
\hline & Suhu $\left({ }^{\circ} \mathrm{C}\right)$ & Kimia & & & \\
\hline \multirow[t]{3}{*}{$\mathrm{Cd}^{2+}$} & 300 & & 6,08 & 7,51 & (Gao et al., 2019) \\
\hline & 500 & - & 8,50 & 9,44 & \\
\hline & 700 & - & 34,80 & 5,49 & \\
\hline \multirow[t]{2}{*}{ As (V) dan Cr(III) } & 300 & $\mathrm{~K}_{2} \mathrm{CO}_{3}$ & 18 & 4,33 & (Agrafioti et al., 2013) \\
\hline & 500 & $\mathrm{~K}_{2} \mathrm{CO}_{3}$ & 90 & 30,12 & \\
\hline $\mathrm{Pb}$ (II) dan $\mathrm{Cr}(\mathrm{VI})$ & 400 & - & 23,7 & 15,3 dan 69,0 & (Zhang et al., 2013) \\
\hline \multirow[t]{3}{*}{$\mathrm{Cu}(\mathrm{II})$ dan $\mathrm{Pb}(\mathrm{II})$} & 500 & $\mathrm{KOH}$ & 68 & - & (Zaini et al., 2014) \\
\hline & 850 & $\mathrm{KOH}$ & 7,3 & - & \\
\hline & 600 & - & 50 & 0,025 & \\
\hline \multirow[t]{3}{*}{$\mathrm{Hg}$} & 750 & - & 49 & 0,03 & (Almquist and Qin, 2013) \\
\hline & 900 & - & 67 & 1,9 & \\
\hline & $<450$ & - & 15 & 20,1 dan 17,6 & \\
\hline \multirow[t]{2}{*}{$\mathrm{Cu}$ dan $\mathrm{Zn}$} & 450 & - & 60 & 17,9 dan 12,8 & (Velghe et al., 2012) \\
\hline & 450 & $\mathrm{HCl}$ & 257 & 19,9 dan 15,8 & \\
\hline \multirow[t]{3}{*}{$\mathrm{Zn} / \mathrm{Cd}$} & - & - & 2,516 & 11,04 dan 17,41 & (S. Sy et al., 2018; Sy et al., 2016) \\
\hline & 600 & HNO3 & 52,180 & 64,17 dan 30,38 & \\
\hline & 600 & $\mathrm{ZnCl} 2$ & 104.5 & 37,4 dan 47,39 & \\
\hline \multirow[t]{2}{*}{$\mathrm{Cu}$ dan $\mathrm{Pb}$} & 600 & H3PO4 & 118.3 & 46,30 dan 55,9 & (Lin et al., 2012) \\
\hline & 600 & $\mathrm{KOH}$ & 130.7 & 42,0 dan 49,7 & \\
\hline $\mathrm{Cd}(\mathrm{II})$ & 700 & $\mathrm{NaOH}$ & 139 & 100 & (Gómez-Pacheco et al., 2012) \\
\hline
\end{tabular}

\section{Pengaruh kondisi persiapan dan aktivasi terhadap penyerapan logam}

Pada Tabel 4 dapat dilihat bahwa sifat dan kapasitas adsorpsi logam berat dapat dipengaruhi oleh kondisi persiapan dan aktivasi ABL. Telah diamati dari literatur bahwa kapasitas adsorpsi dari adsorben berbasis lumpur meningkat dengan peningkatan suhu pirolisis karena perkembangan luas permukaan yang tinggi dan porositas pada suhu pirolisis yang lebih tinggi dimana luas permukaan prekursor lumpur porositas rendah $\left(6,8 \mathrm{~m}^{2} / \mathrm{g}\right)$ meningkat menjadi $34,8 \mathrm{~m}^{2} / \mathrm{g}$ dengan meningkatkan suhu pirolisis dari suhu $300^{\circ} \mathrm{C}$ menjadi $700^{\circ} \mathrm{C}$ degan menggunakan gas nitrogen (Gao et al., 2019). Begitu juga telah dilaporkan, dari suhu $300^{\circ} \mathrm{C}$ menjadi $500^{\circ} \mathrm{C}$ menggunakan nitrogen dapat meningkatkan SBET dari $1,8 \mathrm{~m}^{2} / \mathrm{g}$ menjadi $90 \mathrm{~m}^{2} / \mathrm{g}$ (Agrafioti et al., 2013).

Penelitian lain (Almquist and Qin, 2013) membandingkan kapasitas adsorpsi dari lumpur kertas deinked yang dipirolisis pada $600^{\circ} \mathrm{C}, 750^{\circ} \mathrm{C}$, dan $900^{\circ} \mathrm{C}$. penelitian ini menemukan bahwa adsorben yang dipirolisis pada $900^{\circ} \mathrm{C}$ paling efisien dalam penjerapan Hg. Perbedaan dalam kapasitas adsorpsi dari adsorben berbasis lumpur yang berbeda disebabkan oleh derajat karbonisasi dan sifat gugus fungsi pada permukaan bahan penyerap.

Sejumlah peneliti telah mempelajari efek pirolisis/ waktu aktivasi dan suhu pada struktur berpori dari bahan karbon. Penelitian yang dilakukan (Zhang et al., 2013) telah menunjukkan bahwa luas permukaan BET dari arang lumpur meningkat dengan waktu aktivasi, karena waktu aktivasi yang lebih lama memberikan lebih banyak waktu bagi karbon untuk bereaksi dengan zat pengaktif. Selain itu, suhu aktivasi yang lebih tinggi memungkinkan laju reaksi yang lebih tinggi, sehingga menghasilkan lebih banyak pori.

Berbagai prosedur aktivasi digunakan untuk meningkatkan adsorpsi kapasitas adsorben berbasis lumpur. Aktivasi fisik dan aktivasi kimia adalah dua prosedur aktivasi yang umum digunakan. Penggunaan agen aktivasi kimia seperti $\mathrm{ZnCl}_{2}, \mathrm{H}_{2} \mathrm{SO}_{4}, \mathrm{KOH}, \mathrm{NaOH}$, $\mathrm{K}_{2} \mathrm{CO}_{3}, \mathrm{H}_{3} \mathrm{PO}_{4}$ dan $\mathrm{H}_{2} \mathrm{O}_{2}$ dan asam sitrat umumnya dilaporkan dalam literatur. Rasio agen aktivasi terhadap lumpur, waktu aktivasi, suhu karbonisasi, suhu aktivasi dan metode aktivasi dilaporkan sebagai faktor penting dalam proses modifikasi/aktivasi adsorben berbasis lumpur. Konsentrasi aktivator yang optimal tergantung pada jenis lumpur dan jenis zat pengaktifan. Penelitian yang dilaporkan oleh (Xi and Guo, 2013) mengatakan bahwa efisiensi penjerapan $\mathrm{Cr}(\mathrm{VI})$ maksimum dicapai pada kondisi optimal berikut: proporsi rendam - 1: 1 (w / v), waktu perendaman - 8 jam dan waktu pirolisis - 30 menit. Umumnya, kapasitas adsorpsi dan luas permukaan BET dari ABL meningkat dengan peningkatan rasio agen aktivasi terhadap $\mathrm{ABL}$, karena pembentukan pori-pori yang meningkat. Namun, 
peningkatan rasio agen aktivasi terhadap ABL di luar nilai optimum juga dapat berpengaruh negatif terhadap kapasitas adsorpsi dan luas permukaan BET karena kerusakan mikroporositas dari kerusakan dinding pori. Selain itu (Lin et al., 2012; Zaini et al., 2014) membandingkan peran agen aktivasi kimia yang berbeda ( $\mathrm{KOH}, \mathrm{ZnCl}_{2}$ dan $\mathrm{H}_{3} \mathrm{PO}_{4}$ ) untuk menyerap $\mathrm{Cu}$ (II) dan $\mathrm{Pb}$ (II) dan menemukan bahwa adsorben yang diaktifkan dengan $\mathrm{H}_{3} \mathrm{PO}_{4}$ berkinerja lebih baik daripada adsorben yang diaktifkan $\mathrm{KOH}$ dan $\mathrm{ZnCl}_{2}$. Sebaliknya, penelitian lain melaporkan $\mathrm{KOH}$ sebagai agen pengaktif terbaik untuk persiapan adsorben dengan menghasilkan luas permukaan yang tinggi (Zaini et al., 2014, 2013).

Beberapa penelitian melaporkan penggunaan aktivasi uap untuk meningkatkan kinerja $\mathrm{ABL}$ dan menemukan bahwa kapasitas adsorpsi adsorben meningkat setelah aktivasi uap karena pelebaran pori oleh pengembangan dan efek ekspansi uap (Hojamberdiev et al., 2008; W. H. Li et al., 2011).

\section{Kesimpulan}

Dari tinjauan literatur didapatkan bahwa adsorben berbasis lumpur (ABL) dapat digunakan untuk menyisihkan berbagai pencemar dalam air limbah sepertti zat warna dan logam. Sejalan dengan itu ABL juga dapat digunakan sebagai metode alternatif untuk pembuangan dan daur ulang limbah lumpur aktif (LLA) yang ada. Sifat adsorben bervariasi tergantung pada jenis lumpur, suhu waktu karbonisasi dan jenis aktivator dan kondisi waktu aktivasi yang digunakan. Telah dilaporkan bahwa aktivasi kimiawi menggunakan berbagai jenis aktivator menghasilkan adsorben yang jauh lebih unggul dengan luas spesifik area yang tinggi dibandingkan dengan metode aktivasi secara fisika. Disamping itu pada proses aktifvasi fisika sendiri, dilaporkan bahwa sejalan dengan semakin tinggi suhu pirolisis dan suhu aktivasi, maka semakin dapat meningkatkan luas spesifik area sehingga dapat meningkatkan kapasitas penjerapan zat warna dan logam dalam larutan

\section{Daftar pustaka}

Abbas, M., Zaini, A., Yuhana, N., 2017. Evaluation of treated and untreated sludge from yarn processing factory as adsorbent candidates for dye removal 44 , 508-517.

Abo-El-Enein, S.A., Shebl, A., Abo El-Dahab, S.A., 2017. Drinking water treatment sludge as an efficient adsorbent for heavy metals removal. Appl. Clay Sci. 146, 343-349. https://doi.org/10.1016/j.clay. 2017.06.027

Agrafioti, E., Bouras, G., Kalderis, D., Diamadopoulos, E., 2013. Biochar production by sewage sludge pyrolysis. J. Anal. Appl. Pyrolysis 101, 72-78. https://doi.org/10.1016/j.jaap.2013.02.010

Almquist, C., Qin, N., 2013. Pyrolysis of deinked paper sludge to synthesize adsorbents for elemental $\mathrm{Hg}$ vapors. Environ. Prog. Sustain. Energy 32, 524-534. https://doi.org/10.1002/ep.11652

Athalathil, S., Stüber, F., Bengoa, C., Font, J., Fortuny, A., Fabregat, A., Balaguer, V., 2014. Characterization and performance of carbonaceous materials obtained from exhausted sludges for the anaerobic biodecolorization of the azo dye Acid Orange II. J. Hazard. Mater. 267, 21-30. https://doi.org/10.1016/j.jhazmat.2013.12.031

Boualem, T., Debab, A., Martínez de Yuso, A., Izquierdo, M.T., 2014. Activated carbons obtained from sewage sludge by chemical activation: gasphase environmental applications. J. Environ. Manage. 140, 145-51. https://doi.org/10.1016/ j.jenvman.2014.03.016

Calisto, V., Ferreira, C.I. a., Santos, S.M., Gil, M.V., Otero, M., Esteves, V.I., 2014. Production of adsorbents by pyrolysis of paper mill sludge and application on the removal of citalopram from water. Bioresour. Technol. 166, 335-344. https://doi. org/10.1016/j.biortech.2014.05.047

Chiang, H.L., Lin, K.H., Chiu, H.H., 2012. Exhaust characteristics during the pyrolysis of $\mathrm{ZnCl}_{2}$ immersed biosludge. J. Hazard. Mater. 229-230, 233-244. https://doi.org/10.1016/j.jhazmat. 2012.05.104

Devi, P., Saroha, A.K., 2017. Utilization of sludge based adsorbents for the removal of various pollutants: A review. Sci. Total Environ. 578, 16-33. https:// doi.org/10.1016/j.scitotenv.2016.10.220

Ding, R., Zhang, P., Seredych, M., Bandosz, T.J., 2012. Removal of antibiotics from water using sewage sludge- and waste oil sludge-derived adsorbents. Water Res. 46, 4081-4090. https://doi.org/10.1016/ j.watres.2012.05.013

Gadd, G.M., White, C., 1993. Microbial treatment of metal pollution-a working biotechnology. Bioremediation 11, 353-359.

Gao, L.Y., Deng, J.H., Huang, G.F., Li, K., Cai, K.Z., Liu, Y., Huang, F., 2019. Relative distribution of $\mathrm{Cd}^{2+}$ adsorption mechanisms on biochars derived from rice straw and sewage sludge. Bioresour. Technol. 272, 114-122. https://doi.org/10.1016/j. biortech.2018.09.138

Gómez-Pacheco, C. V., Rivera-Utrilla, J., Sánchez-Polo, M., López-Peñalver, J.J., 2012. Optimization of the preparation process of biological sludge adsorbents for application in water treatment. J. Hazard. Mater. 217-218, 76-84. https://doi.org/10.1016/j.jhazmat. 2012.02.067

Hadi, P., Xu, M., Ning, C., Sze Ki Lin, C., McKay, G., 2015. A critical review on preparation, characterization and utilization of sludge-derived activated carbons for wastewater treatment. Chem. Eng. J. https://doi.org/10.1016/j.cej.2014.08.088

Hojamberdiev, M., Kameshima, Y., Nakajima, A., Okada, K., Kadirova, Z., 2008. Preparation and sorption properties of materials from paper sludge. J. Hazard. Mater. 151, 710-719. https://doi.org/ 10.1016/j.jhazmat.2007.06.058

Jindarom, C., Meeyoo, V., Kitiyanan, B., Rirksomboon, T., Rangsunvigit, P., 2007. Surface characterization and dye adsorptive capacities of char obtained from pyrolysis/gasification of sewage sludge. Chem. Eng. J. 133, 239-246. https://doi.org/10.1016/j.cej. 2007.02.002

Li, W.-H., Yue, Q.-Y., Gao, B.-Y., Wang, X.-J., Qi, Y.F., Zhao, Y.-Q., Li, Y.-J., 2011. Preparation of 
sludge-based activated carbon made from paper mill sewage sludge by steam activation for dye wastewater treatment. Desalination 278, 179-185. https://doi.org/10.1016/j.desal.2011.05.020

Li, W.H., Yue, Q.Y., Gao, B.Y., Wang, X.J., Qi, Y.F., Zhao, Y.Q., Li, Y.J., 2011. Preparation of sludgebased activated carbon made from paper mill sewage sludge by steam activation for dye wastewater treatment. Desalination 278, 179-185.

Lin, Q.H., Cheng, H., Chen, G.Y., 2012. Preparation and characterization of carbonaceous adsorbents from sewage sludge using a pilot-scale microwave heating equipment. J. Anal. Appl. Pyrolysis 93, 113-119. https://doi.org/10.1016/j.jaap.2011.10.006

Mahapatra, K., Ramteke, D.S., Paliwal, L.J., 2012. Production of activated carbon from sludge of food processing industry under controlled pyrolysis and its application for methylene blue removal. J. Anal. Appl. Pyrolysis 95, 79-86. https://doi.org/10.1016/ j.jaap.2012.01.009

Monsalvo, V.M., Mohedano, A.F., Rodriguez, J.J., 2011. Activated carbons from sewage sludge. Application to aqueous-phase adsorption of 4-chlorophenol. Desalination 277, 377-382. https://doi.org/10.1016/ j.desal.2011.04.059

Naiya, T.K., Bhattacharya, A.K., Das, S.K., 2008. Removal of $\mathrm{Cd}(\mathrm{II})$ from aqueous solutions using clarified sludge. J. Colloid Interface Sci. 325, 48-56. https://doi.org/10.1016/j.jcis.2008.06.003

Nielsen, L., Zhang, P., Bandosz, T.J., 2015. Adsorption of carbamazepine on sludge/fish waste derived adsorbents: Effect of surface chemistry and texture. Chem. Eng. J. 267, 170-181. https://doi.org/10.1016/ j.cej.2014.12.113

Pan, Z.H., Tian, J.Y., Xu, G.R., Li, J.J., Li, G.B., 2011. Characteristics of adsorbents made from biological, chemical and hybrid sludges and their effect on organics removal in wastewater treatment. Water Res. 45, 819-827. https://doi.org/10.1016/j.watres. 2010.09.008

Rio, S., Le Coq, L., Faur, C., Le Cloirec, P., 2006. Production of porous carbonaceous adsorbent from physical activation of sewage sludge: Application to wastewater treatment. Water Sci. Technol. 53, 237244. https://doi.org/10.2166/wst.2006.102

Salmariza, S., 2012. Pemanfaatan limbah lumpur proses activated sludge industri karet remah sebagai adsorben. J. Ris. Ind. VI, 175-182.

Samolada, M.C., Zabaniotou, A.A., 2014. Comparative assessment of municipal sewage sludge incineration, gasification and pyrolysis for a sustainable sludge-toenergy management in Greece. Waste Manag. 34, $411-420$. https://doi.org/10.1016/j.wasman.2013.11.003

Smith, K.M., Fowler, G.D., Pullket, S., Graham, N.J.D., 2009. Sewage sludge-based adsorbents: A review of their production, properties and use in water treatment applications. Water Res. 43, 2569-2594.

Spellman, F., 2014. Handbook of water and wastewater treatment plant operations, third. ed. CRC Press, New York.
Sy, S., Harmiwati, Kurniawati, D., Aziz, H., Chaidir, Z., Zein, R., 2018. Removal of Zinc onto several adsorbents derived from waste activated sludge of crumb rubber industry (CRI-WAS). Int. J. Adv. Sci. Eng. Inf. Technol. 8, 157-164. https://doi.org/ 10.18517/ijaseit.8.1.4084

Sy, Salmariza, Kurniawati, D., Lestari, I., Harmiwati, H., Kasman, M., 2018a. Pengaruh pH dan dosis adsorben dari limbah lumpur aktif industri crumb rubber terhadap kapasitas penyerapan ion $\mathrm{Cd}(\mathrm{II})$ dan $\mathrm{Zn}(\mathrm{II})$. J. Litbang Ind. 8, 95. https://doi.org/10.24960/jli. v8i2.4290.95-104

Sy, S., Lestari, I., Kurniawati, D., Aziz, H., Chaidir, Z., Zein, R., 2016. Characterization of waste activated sludge of crumb rubber industry (CRI-WAS) as Adsorbent of Cd(II). Der Pharma Chem. 8, 228-235.

Sy, Salmariza, Sofyan, Ardinal, Harmiwati, Kasman, M., Zein, R., 2018b. The ability of three types of adsorbents prepared from waste activated sludge of crumb rubber industry (CRI-WAS) for Cd(II) ion removal, in: AIP Conference Proceedings. AIP Publishing LLC , p. 020035. https://doi.org/10.1063/ 1.5082440

Turovskiy, I.S., Mathai, P.K., 2005. Wastewater sludge processing, wastewater sludge processing. John Wiley and Sons.

Velghe, I., Carleer, R., Yperman, J., Schreurs, S., D'Haen, J., 2012. Characterisation of adsorbents prepared by pyrolysis of sludge and sludge/disposal filter cake mix. Water Res. 46, 2783-2794. https://doi.org/10.1016/j.watres.2012.02.034

Xi, X., Guo, X., 2013. Preparation of bio-charcoal from sewage sludge and its performance on removal of $\mathrm{Cr}$ (VI) from aqueous solutions. J. Mol. Liq. 183, 26-30. https://doi.org/10.1016/j.molliq.2013.03.020

Xu, G., Yang, X., Spinosa, L., 2015. Development of sludge-based adsorbents: Preparation, characterization, utilization and its feasibility assessment. J. Environ. Manage. 151, 221-232. https://doi.org/10.1016/j.jenvman.2014.08.001

Zaini, M.A.A., Zakaria, M., Alias, N., Zakaria, Z.Y., Johari, A., Setapar, S.H.M., Kamaruddin, M.J., Yunus, M.A.C., 2014. Removal of heavy metals onto koh-activated ash-rich sludge adsorbent. energy procedia 61, 2572-2575. https://doi.org/10.1016/ j.egypro.2014.12.048

Zaini, M.A.A., Zakaria, M., Mohd.-Setapar, S.H., CheYunus, M.A., 2013. Sludge-adsorbents from palm oil mill effluent for methylene blue removal. J. Environ. Chem. Eng. 1, 1091-1098. https://doi.org/10.1016/ j.jece.2013.08.026

Zhang, W., Mao, S., Chen, H., Huang, L., Qiu, R., 2013. $\mathrm{Pb}(\mathrm{II})$ and $\mathrm{Cr}(\mathrm{VI})$ sorption by biochars pyrolyzed from the municipal wastewater sludge under different heating conditions. Bioresour. Technol. 147, 545552. https://doi.org/10.1016/j.biortech.2013.08.082

Zou, J., Dai, Y., Wang, X., Ren, Z., Tian, C., Pan, K., Li, S., Abuobeidah, M., Fu, H., 2013. Structure and adsorption properties of sewage sludge-derived carbon with removal of inorganic impurities and high porosity. Bioresour. Technol. 142, 209-217. https://doi.org/10.1016/j.biortech.2013.04.064 